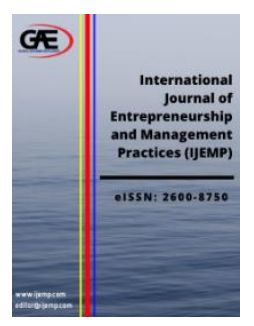

\author{
International Journal of Entrepreneurship and \\ Management Practices (IJEMP) \\ Journal Website: http://ijemp.com/ \\ eISSN: $2600-8750$
}

\title{
THE EFFECTIVENESS OF ENTREPRENEURSHIP TRAINING PROGRAMS TOWARDS THE BUMIPUTERA ENTREPRENEURIAL PERFORMANCE IN JOHOR
}

\author{
Nuraisya Maisara Md Noor Aizuddin ${ }^{1 *}$, Dr Sabrinah Adam² $^{2}$ Dr Beni Widarman ${ }^{3}$ \\ 1 Azman Hashim International Business School, Universiti Teknologi Malaysia (UTM), Malaysia. \\ Email: nuraisyamaisara@graduate.utm.my \\ 2 Azman Hashim International Business School, Universiti Teknologi Malaysia (UTM), Malaysia. \\ Email: sabrinah@utm.my \\ 3 Azman Hashim International Business School, Universiti Teknologi Malaysia (UTM), Malaysia. \\ Email: beni@utm.my \\ Corresponding Author
}

\section{Article Info:}

Article history:

Received date: 31.05 .2020

Revised date: 03.06.2020

Accepted date: 14.06 .2020

Published date: 15.06 .2020

\section{To cite this document:}

Aizuddin, N. M. M. N., Adam, S., \& Widarman, B. (2020). The Effectiveness of Entrepreneurship Training Programs towards The Bumiputera Entrepreneurial Performance in Johor. International Journal of Entrepreneurship and Management Practices, 3 (10), 74-81.

DOI: $10.35631 /$ IJEMP.310006.

\begin{abstract}
:
The study aimed to assess the effectiveness of entrepreneurship training towards the level of Bumiputera entrepreneurial performances in Johor. Action research was applied in the study and intervention plan was designed to examine the changes of Bumiputera entrepreneurial performances. The study used a mixed method for data collection which consists of qualitative and quantitative methods. 4 respondents for the qualitative method and a number of 217 from a total population of 500 Bumiputera entrepreneurs will be used as respondents for the study. The data collected from the mixed method will be analysed using Miles and Huberman Technique and SPSS version 25.
\end{abstract}

Keywords:

Entrepreneurship Training, Entrepreneurial Performances, Entrepreneurial Skills

\section{Introduction}

Entrepreneurial performance (EP) of an entrepreneur will be better when they are equipped with superior entrepreneurship knowledge (Audretsch, 2007). The indicators to measure entrepreneurial performance among entrepreneurs is through financial and non-financial measure. Management skills, competency, knowledge and motivation are indicators that can impact entrepreneurial performance through non-financial measure (Mamun, 2019). EP is important as it can contribute to increase in success of enterprises. Apart from that greater EP 
of entrepreneurs that come from informal and formal sector is important as has significant impact on the economic growth (Mamun, 2019).

In recent years, the entrepreneurship field has been getting attention and lead to a growing number of entrepreneurship training programs that are provided for entrepreneurs by various institutions. The aim of entrepreneurship training program is to fulfilled entrepreneurs with entrepreneurship knowledge by supplying input and evaluating the output of the entrepreneurs, (Coelho, 2014). The entrepreneurship training program can enhance the entrepreneur's knowledge, skills and behavior and can contribute to increase in their performance (Warhuus, 2017).

Various entrepreneurship training program has been conducted however, there is not enough evidence whether the training programs conducted are effective. There is a lack in measuring the effectiveness of programs towards the entrepreneurs. The development of these entrepreneurship training programs are conducted without reflection on its effectiveness among entrepreneurs (Nasr, 2014). Besides assessing the content and method of an entrepreneurship program, it is important to evaluate whether the program conducted is effective in creating values on the entrepreneurs (Galvao, 2019).

\section{Literature Review}

\section{Entrepreneurship Training}

Entrepreneurship is the process of creating a business and the willingness to take financial risks in order to gain profit. Entrepreneurship plays an important role as it gives impact on job opportunity, economy and innovations (Frese \& Gielnik, 2014). The effectiveness of training program is essential in order to assess the entrepreneurial skills among entrepreneurs. An effective training program will make entrepreneurs have more knowledge and become more competent in developing their enterprises.

Various research on entrepreneurship field has been conducted before. Previous researches reached an agreement where entrepreneurship is a thing that is developed when individuals are educated with entrepreneurship knowledge and also through their life experiences (Gedeon, 2017). Individuals will be able to acquire entrepreneurship traits through engaging in entrepreneurship training programs (Galvao \& Marques, 2018).

\section{Entrepreneurial Performance}

Entrepreneurial performance (EP) refers to the level of achievement of an entrepreneur (Hasan, 2016). Whether it is based on skills they acquired or level of profit that their business achieved. Besides, EP also can be refers to the action of an entrepreneur that contribute to their business. The action involves on what entrepreneurs does in order to achieve desired business achievement. The EP of an entrepreneur is mostly influence by their skill, individual traits and social factors. Apart from that, entrepreneurial knowledge and abilities can be the factor that can impact EP. 


\section{Relevant Model}

\section{Conceptual Model of Entrepreneurship}

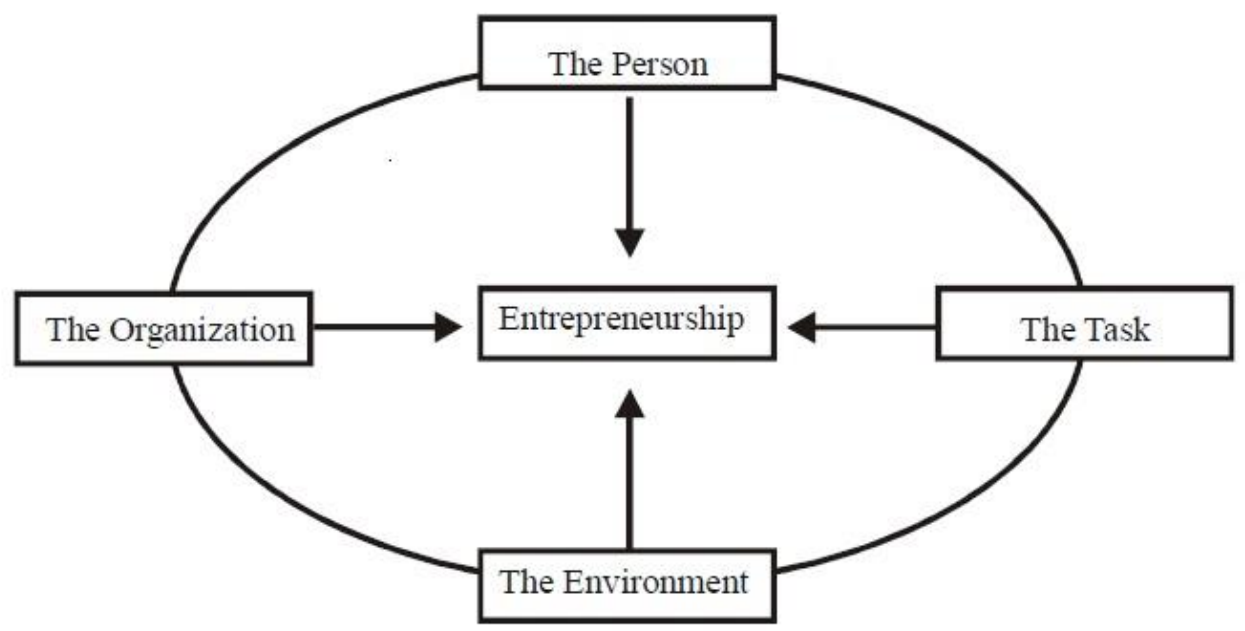

Figure 1: The Conceptual Model of Entrepreneurship

Source: (John J. Kao, 1989)

The figure 1 above shows the conceptual model of entrepreneurship. The model shows the factors that involve in entrepreneurship development. The factors consist of the person, task, organization and environment. In this study, researcher will focus more on the person based on the model. From the model, an individual that perceived specific traits, skills and motivation will contribute to entrepreneurship.

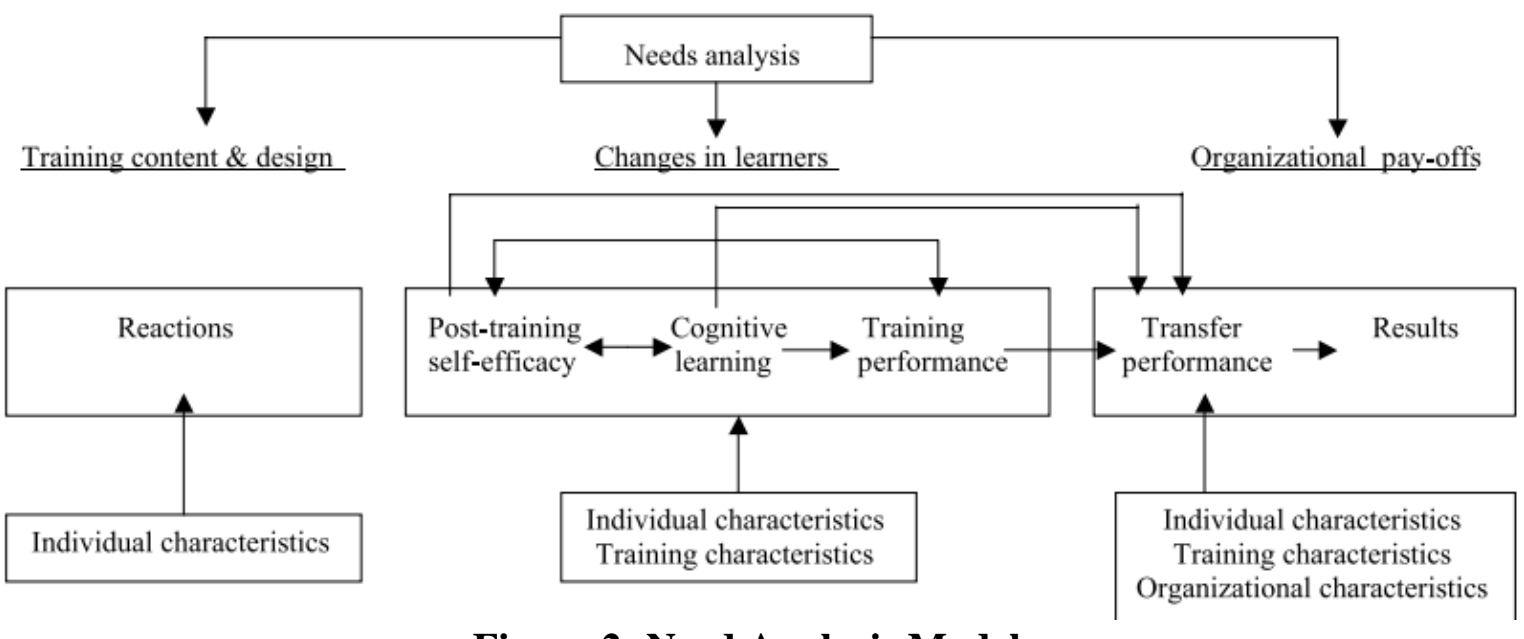

Source: (Alvarez et al, 2004)

Figure 2: Need Analysis Model

The model in figure 2 above shows the need analysis model. For this study, researcher only focuses on the changes in learners. This model is used to identify whether there are any changes in entrepreneurs after participating in entrepreneurship training program (Byrne, 2009). The model breaks the changes in learners to 3 elements which are self-efficacy, cognitive learning and training performance. Self-efficacy refers to the ability of a person in adapting to entrepreneurial behaviour. 


\section{The Relationship between Entrepreneurship Conceptual Model and Need Analysis Model}

In the entrepreneurship conceptual model, it is indicated that the person itself can give influence on the entrepreneurship development. A person must be able to acquire certain entrepreneurial skills, knowledge and behaviour in order to build success in entrepreneurship. Based on the need analysis model, it is necessary to evaluate the changes that occur in entrepreneurs in order to determine whether the entrepreneurs possess entrepreneurial skills and behaviour from the training programs.

\section{Intervention Plan}

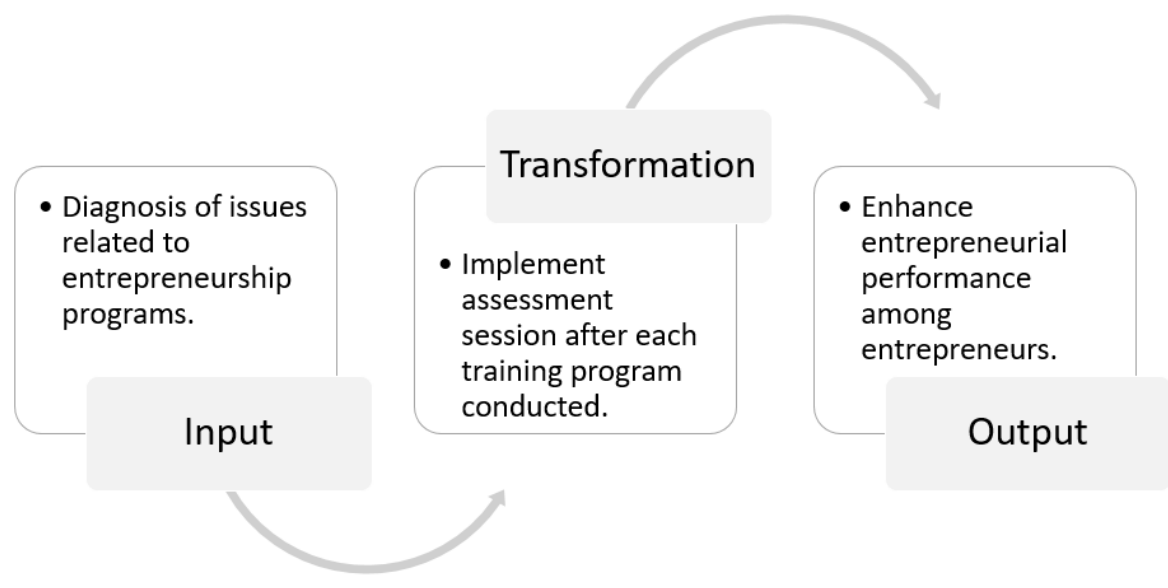

Figure 3: Propose Plan Based on Lewin Model of Change

The intervention plan in the study is proposed by using Lewin's Model of Change. It consists of 3 stages which are input, transformation and output. In the input stage, researcher will discuss with the organization's supervisors on how to improve the entrepreneurship training programs. An interview also will be conducted with several entrepreneurs to get their idea on how to make the training programs become more effective. In transformation stage, an assessment session approach will be conduct among entrepreneurs after each training program. This approach is conduct in order to identify whether entrepreneurs are fully understand and ensure that they are able to adapt on what they have learn in the training program that they participate. Lastly is the output stage. In this stage, the entrepreneurial performance possess by entrepreneurs will be measure by conducting post survey. 


\section{Method}

\section{Action Research as Research Design}

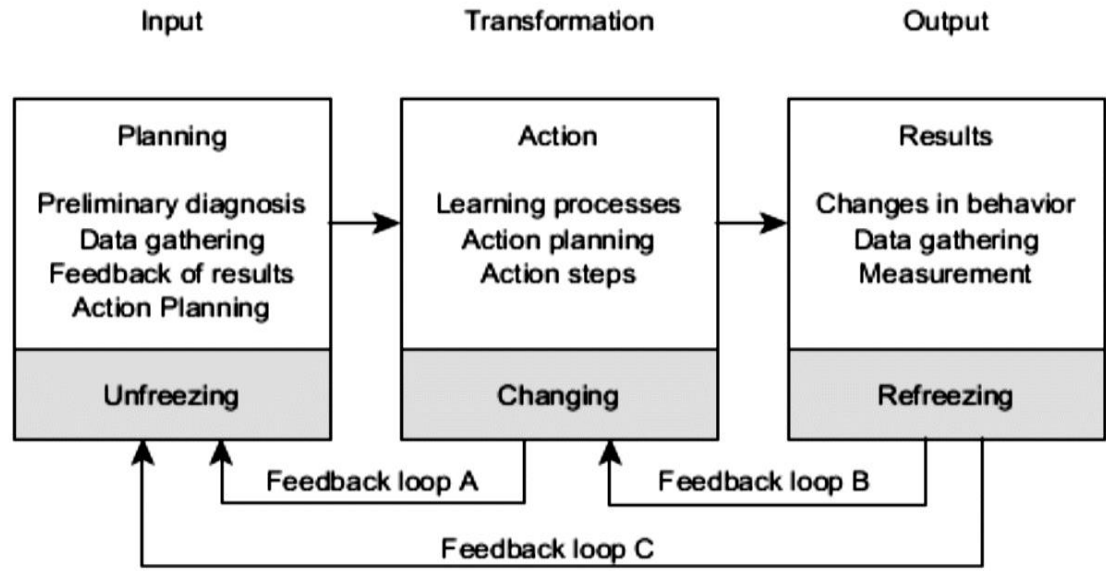

Figure 4: 3 Stage of Change Model (Lewin, 1958)

This study uses action research approach as the research design. Action research is the process to solve problematic situation or recommendation to improve the current problematic practices in an organization (Husin, Alias \& Ismail, 2013). The researcher that is involved in action research will cooperate with the practitioner in order to overcome the problematic situation by implementing solutions (Hussin, Ismail, \& Alias, 2015). Action research consists of three stages which are planning, action and results. In the first stages which is planning, several planning action will be derived from the diagnosis of problematic situation. Data collection, preliminary diagnosis and feedback of result will be analysed from this input phase.

Next is action or can be refer as the transformation phase. The action stage consists of the intervention plan that will be implemented in order to examine the changes in the organization. At this phase, action plan will be performed to observe any behavioural changes in the organization. Lastly, in the output phase, any changes on the behaviour after the intervention will be analysed to determine whether the action plan is successful or not. Data will be collected from the participant in order to analyse the changes through primary data collection.

\section{Pragmatism}

Pragmatism research philosophy is applied in the study. Most mixed method study will uses pragmatism as the philosophy of research. Pragmatism philosophy is a problem oriented philosophy and it will help to answer the research questions effectively. (Lewis, Thornhill \& Saunder, 2009).

\section{Qualitative}

Qualitative method is used to obtain opinion or reasons in a research. It can be refers as a type of method that collect non numerical data that is needed to be interpret in order to identify the meaning behind it. Data collected from observation, interviews and documents is a part of qualitative method (Maxwell \& Reybold, 2015).

\section{Quantitative}

Quantitative method technique consists of experiments and survey. This method uses numerical system to measure the variables. The objective to collect the data using quantitative 
method is to describe and understand the nature of phenomenon in the study specifically on model and theories (Rowley, 2014).

\section{Unit of Analysis}

Unit of analysis refers to the entity that is analysed in the study. A sample size of 217 from 500 population of MARA entrepreneurs was chosen for the study.

\section{Sampling Technique}

The sampling techniques used in the study is purposive sampling for qualitative method. Purposive sampling is selected based on the purpose of the study. This sample is selected based on specific characteristic. It is a non-probability sampling and mainly known as subjective and selective sampling (Robinson, 2014). Purposive sampling will be used when researcher want to study a particular set of people as they match with a specific profile.

In quantitative method, the sampling technique used is stratified sampling. The sample will be chosen based on the entrepreneurs that registered their business with Companies Comission of Malaysia (CCM) and registered as participants of MARA entrepreneurship programs.

\section{Validity}

Validity can be described as the accuracy of the method used to conduct the study. For the purpose of the study, the questionnaires is validated by 2 academicians and 2 practitioners of the case company. Validity of questionnaires is conducted in order to test whether the tools used in determining the critical elements in research is appropriate (DePoy \& Gitlin, 2016).

\section{Reliability}

The reliability of research refers to whether the research instruments used in the study will gives consistent results. Reliability can be describes as the consistency of findings regardless of whatever the instrument measures (Yaqoot et al., 2017). Cronbach alpha in Pilot test will represent the internal consistency of the analysis. Pilot test is used to measure the scale of reliability (Papadopoulos \& Giovanis, 2018).

\section{Data Analysis}

The data collected from the questionnaire will be analysed using the Statistical Package for Social Sciences (SPSS) software version 25. The data analysis of the study consists of descriptive analysis which will analyse the mean, median, standard deviation and variance in the study. Besides, several test will be conducted such as Normality test and Reliability test. Table 1 below shows the research questions and research approaches that will be used in the study.

Table 1: Research Question and Approaches

\begin{tabular}{clcc}
\hline No. & \multicolumn{1}{c}{ Research Questions } & Approach & SPP \\
\hline 1. & $\begin{array}{l}\text { What improvement that } \\
\text { can be done to assess } \\
\text { entrepreneurial } \\
\text { performance? }\end{array}$ & $\begin{array}{l}\text { Qualitative } \\
\text { Method- }\end{array}$ & \\
2. & $\begin{array}{l}\text { What are the impact of } \\
\text { entrepreneurship programs } \\
\text { towards entrepreneur's } \\
\text { entrepreneurial } \\
\text { performances? }\end{array}$ & $\begin{array}{c}\text { Quantitative } \\
\text { Method- }\end{array}$ & $\begin{array}{c}\text { Muberman } \\
\text { Technique }\end{array}$ \\
& Questionnaires & (2014), SPSS \\
\end{tabular}




\section{Result}

\section{Reliability Test}

Reliability test is conducted in order to measure the consistency of the study. The table 2 below shows the Cronbach's Alpha that is obtained for the study.

Table 2: Reliability Test

\begin{tabular}{lcc}
\hline \multicolumn{1}{c}{ Variables } & Items & $\begin{array}{c}\text { Cronbach's } \\
\text { Alpha }\end{array}$ \\
\hline Business management skill & 6 & 0.797 \\
Marketing skill & 7 & 0.862 \\
Problem solving skill & 6 & 0.778 \\
$\begin{array}{l}\text { Opportunity recognition } \\
\text { skill }\end{array}$ & 4 & 0.817 \\
\hline
\end{tabular}

\section{Conclusion}

Assessing the effectiveness of entrepreneurship training program is important as it is certainly gives impact on entrepreneurs. The evaluation of entrepreneurs after training is crucial to conduct in order to identify whether the entrepreneurs are able to perform specific skill from what they have learned from the program. Thus, this research suggest to implement intervention such as assessment of entrepreneurs after they have participated in the training program. This is to enhance their entrepreneurial performance and ensure that they are able to manage their enterprises successfully.

\section{References}

Al Mamun, A., Fazal, S. A., \& Muniady, R. (2019). Entrepreneurial knowledge, skills, competencies and performance. Asia Pacific Journal of Innovation and Entrepreneurship. https://doi.org/10.1108/apjie-11-2018-0067

Byrne, J., \& Fayolle, A. (2009). Corporate Entrepreneurship Training Evaluation: A Model and a New Research Perspective. Industry and Higher Education, 23(3), 163-174. https://doi.org/10.5367/000000009788640242

Coelho, F.J.M., Marques, C., Loureiro, A. and Ratten, V. (2018), "Evaluation of the impact of an entrepreneurship training program in Recife, Brazil", Journal of Entrepreneurship in Emerging Economies, Vol. 10 No. 3, pp. 472-488. https://doi.org/10.1108/JEEE-102017-0077

DePoy, E., \& Gitlin, L. N. (2016). Mixed Method Designs. In Introduction to Research. https://doi.org/10.1016/b978-0-323-26171-5.00012-4

Fatima S.M.A Hasan Muneer Mohammed Saeed Almubarak , (2016),"Factors influencing women entrepreneurs' performance in SMEs", World Journal of Entrepreneurship, Management and Sustainable Development, Vol. 12 Iss 2 pp. $82-101$

Frese, M., \& Gielnik, M. M. (2014). The Psychology of Entrepreneurship. Annual Review of Organizational Psychology and Organizational Behavior. https://doi.org/10.1146/annurev-orgpsych-031413-091326

Galvão, A., Marques, C. and Ferreira, J.J. (2020), "The role of entrepreneurship education and training programmes in advancing entrepreneurial skills and new ventures", European Journal of Training and Development, Vol. ahead-of-print No. ahead-of-print. https://doi.org/10.1108/EJTD-10-2019-0174

Gedeon, S. A. (2017). Measuring Student Transformation in Entrepreneurship Education Programs. Education Research International, 2017, 1-12. doi:10.1155/2017/8475460 
Hussin, M. R. A., Ismail, K., \& Alias, R. A. (2015). Understanding the development process of a training programme curriculum for small and medium enterprises in Malaysia. International Journal of Entrepreneurship and Small Business. https://doi.org/10.1504/IJESB.2015.068640

Maxwell, J. A., \& Reybold, L. E. (2015). Qualitative Research. In International Encyclopedia of the Social \& Behavioral Sciences: Second Edition. https://doi.org/10.1016/B978-008-097086-8.10558-6

Miles, M. B., Huberman, A. M., \& Saldaäna, J. (2014). Qualitative data analysis: A methods sourcebook (Third edition.). Thousand Oaks, Califorinia: SAGE Publications, Inc.

Nasr, K. B., \& Boujelbene, Y. (2014). Assessing the Impact of Entrepreneurship Education. Procedia - Social and Behavioral Sciences, 109, 712-715. doi: 10.1016/j.sbspro.2013.12.534

Papadopoulos, V., \& Giovanis, D. G. (2018). Reliability analysis. In Mathematical Engineering. https://doi.org/10.1007/978-3-319-64528-5_4

Robinson, R. S. (2014). Purposive Sampling. In Encyclopedia of Quality of Life and WellBeing Research. https://doi.org/10.1007/978-94-007-0753-5_2337

Rowley, J. (2014). Designing and using research questionnaires. Management Research Review. https://doi.org/10.1108/MRR-02-2013-0027

Sedgwick, P. (2014). Cross sectional studies: Advantages and disadvantages. BMJ (Online). https://doi.org/10.1136/bmj.g2276

Warhuus, J.P., Tanggaard, L., Robinson, S. and Ernø, S.M. (2017), "From I to We: collaboration in entrepreneurship education and learning?", Education + Training, Vol. 59 No. 3, pp. 234-249. https://doi.org/10.1108/ET-08-2015-0077

Yaqoot, E. S. I., Noor, W. S. W. M., \& Isa, M. F. M. (2017). Factors Influencing Training Effectiveness: Evidence from Public Sector in Bahrain. Economica. 